\title{
Effect of Irrigation Water and Organic Fertilizer on Reducing Nitrate Accumulation and Boosting Lettuce Productivity
}

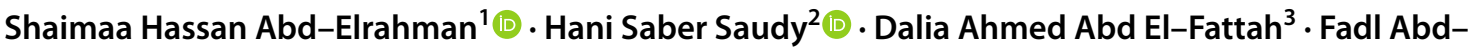 \\ Elhamid Hashem ${ }^{3}$
}

Received: 18 October 2021 / Accepted: 4 February 2022 / Published online: 17 February 2022

(c) The Author(s) 2022

\begin{abstract}
Accumulation of high level of nitrate $\left(\mathrm{NO}_{3}{ }^{-}\right.$) in leaves is a serious issue for vegetable crops like lettuce (Lactuca sativa L.). Therefore, this study aimed to limit $\mathrm{NO}_{3}{ }^{-}$level by adjusting the balance between fertilization and irrigation program in lettuce. In a strip plot design with three replicates, lettuce plants were grown under four fertilizer treatments and three irrigation regimes. Three organic fertilizers (biochar, compost and vermicompost), in addition to mineral fertilizer, were used. The irrigation regimes were 60, 80 and 100\% of crop evapotranspiration, ETc (ETc60, ETc80, and ETc100). Nitrogen (N), phosphorus $(\mathrm{P})$ potassium $(\mathrm{K})$ and organic matter $(\mathrm{OM})$ in soil as well as yield, $\mathrm{N}, \mathrm{P}, \mathrm{K}$ and $\mathrm{NO}_{3}{ }^{-}$of lettuce were estimated. Findings showed that vermicompost or biochar (with any irrigation regime) as well as compost with irrigation by ETc60 were the effective combinations for increasing K content in soil after harvest. Under irrigation by ETc 80 or ETc100, vermicompost or biochar were the efficient treatments for increasing lettuce yield equaling the farmer common practice (ETc100 $\mathrm{x}$ mineral fertilizer). Under irrigation by ETc60, mineral fertilizer or vermicompost showed the highest lettuce leaf content of K. Moreover, ETc60 or ETc 80 x mineral fertilizer recorded the maximum $\mathrm{NO}_{3}{ }^{-}$content of lettuce leaves. The accumulation of nitrate in lettuce leaves owing to mineral fertilizer reached about 1.24 times than that of organic fertilizers. Compost $\mathrm{x}$ ETc80 or ETc100 showed the minimal $\mathrm{NO}_{3}-\mathrm{N}$ accumulation, hence, high relative reductions in $\mathrm{NO}_{3}-\mathrm{N}$ accumulation as compared to the common practice (ETc100 x mineral fertilizer) were observed. In conclusion, irrigation by $80 \%$ instead of $100 \%$ of crop evapotranspiration of organically fertilized lettuce (especially with vermicompost) could be adopted since such practice recorded high lettuce productivity with low $\mathrm{NO}_{3}{ }^{-}$content.
\end{abstract}

Keywords Irrigation pattern $\cdot$ Leaf nitrate content $\cdot$ Lettuce yield $\cdot$ Nutritional value $\cdot$ Slow-release fertilizer $\cdot$ Soil water content

\section{Introduction}

Lettuce (Lactuca sativa L.) is a leafy vegetable crop regarded as one of the major greenhouse-grown plants, owing to its high productivity and economic value (Kř́stková et al.

Hani Saber Saudy

hani_saudy@agr.asu.edu.eg

1 Soil and Water Department, Faculty of Agriculture, Ain Shams University, P.O. Box 68-Hadayek Shoubra, Cairo 11241, Egypt

2 Agronomy Department, Faculty of Agriculture, Ain Shams University, P.O. Box 68-Hadayek Shoubra, Cairo 11241, Egypt

3 Central Laboratory for Agricultural Climate, Agricultural Research Center, P.O. Box 12411, Giza, Egypt
2008). Lettuce has been counted as a significant functional food because of containing vitamins and minerals (Kim et al. 2016). However, high amount of nitrate $\left(\mathrm{NO}_{3}{ }^{-}\right)$could accumulate in leaves of lettuce (Kmecl et al. 2017; Zandvakili et al. 2019). The danger of $\mathrm{NO}_{3}{ }^{-}$is that it turns into nitrites $\left(\mathrm{NO}_{2}{ }^{-}\right.$, toxic compounds) in the gastrointestinal tract of human body (about $5-10 \%$ of absorbed $\mathrm{NO}_{3}^{-}$), causing dangerous diseases (Pinto et al. 2015; Salehzadeh et al. 2020). Thus, the attempts to reduce $\mathrm{NO}_{3}{ }^{-}$in lettuce leaves should be adopted continuously.

The nitrate concentration in vegetable plants varied according to various factors, e.g., nitrogen fertilizer management, light intensity, water stress and soil $\mathrm{pH}$ (Boroujerdnia et al. 2007; Pavlou et al. 2007). Lettuce is highly responsive crop to mineral fertilizers. In this regard, progressive increases in plant height, number of leaves per plant, 
fresh and dry weights, and yield of lettuce were recorded with increasing nitrogen rate (Cercioglu et al. 2012; Tsiakaras et al. 2014). However, with immoderate application of nitrogen fertilizer, vegetables can accumulate high levels of nitrate. Upon being consumed by human, nitrate causes serious health hazards (Umar and Iqbal 2007). Increasing the accumulation of nitrate in lettuce leaves owing to applying mineral fertilizers has been reported (Hoque et al. 2010; Tabaglio et al. 2020). Because reducing nitrate content can add value to vegetable products (Santamaria 2006), organic fertilizers could introduce better solution toward this issue, since lettuce growth, yield and vitamin $\mathrm{C}$ content were higher in the organic production system than conventional systems (Caliskan et al. 2014). Since organic fertilizers provide steady supply of several nutrients and improve physical, chemical and biological properties of the soil, increases in lettuce growth and nutrients concentration and uptake were achieved (Moreira et al. 2014). Compost as an organic source of fertilizers is a valuable product that manipulates soil properties, via improving organic matter content, nutrient availability, aeration and water holding capacity and reducing soil bulk density (Mostafa et al. 2019). Moreover, the use of biochar for soil restoration and biofertilization has increasingly received interest as low-cost and eco-friendly amendment (Lone et al. 2015). Biochar caused a positive impact on soil stability by altering the size of aggregates and regulating soil water, actions that may promote plant growth (Obia et al. 2016). In addition, vermicompost as an organic fertilizer plays a role in enhancing soil fertility, increasing soil-water holding capacity and soil aggregates (AbulSoud et al. 2014). It is rich in many nutrients such as N, P, $\mathrm{K}, \mathrm{Ca}$ and $\mathrm{Mg}$ that are readily available to plant absorption (Hashem and Abd-Elrahman 2016).

Another significant aspect associated with lettuce cultivation is irrigation. Irrigation levels not only affect the yield but also the uptake and accumulation of nitrates in crop plants (Saudy et al. 2020; El-Metwally et al. 2022). Subjecting plant to excessive or deficit water leads to increasing nitrate accumulation (Schiattone et al. 2018). With excessive irrigation, nutrients are highly prone to leaching from the root zone (Maynard and Hochmuth, 2007). Also, irrigation water use efficiency decreased as the irrigation level increased (Bozkurt et al. 2009; El-Metwally et al. 2021). On the other site, Koyama et al. (2012) found that appropriate rhizosphere drought stress decreased the nitrate concentration by $18 \%$ without reducing the yield of lettuce. In this regard, photo-oxidation of plant pigment degradation is regarded as a norm event of oxidative stress resulting from the adverse impact of low water supply. Owing to severe water stress, chloroplast is the first sign to be injured, since it is the master site for production of reactive oxygen species (ROS) (Munné-Bosch and Peñuelas 2003). Also, water deficit promotes production of abscisic acid, which reduces carbon dioxide influx and inhibits photosynthesis by stimulating stomata closure (Chaves et al. 2009; Makhlouf et al. 2022). The paucity of intracellular $\mathrm{CO}_{2}$ due to extended stomatal closure causes the cumulation of ROS and damages the photosynthetic system (Laxa et al. 2019). Additionally, being water deficiency causes turgor loss, reductions in growth rate, foliar expansion, stomatal opening and photosynthesis process were recorded (Bhargava and Sawant 2013). However, the response of lettuce and accumulated nitrate to low water supply at farm level may differ.

The hypothesis of the current work was that the integrated effect of organic fertilizers and watering less than full irrigation could improve soil properties and yield of lettuce with reducing nitrate concentration in leaves. Therefore, the study aimed to investigate the possible changes in soil nutrient status and yield and quality of lettuce resulting from different combinations of organic fertilizers and irrigation regimes.

\section{Materials and Methods}

\subsection{The Experimental Site}

Under open field conditions, a 2-year experiment was carried out during 2018 and 2019 in winter seasons at Dokki Protected Cultivation Experimental Site, Central Laboratory for Agricultural Climate, Agricultural Research Center, Giza Governorate, Egypt. The meteorological data of the experimental site during the two studied seasons are shown in Table 1 . The experimental soil was clay as well as its physical (Klute 1986) and chemical (Page et al. 1982) properties were estimated as shown in Table 2.

\subsection{Plant Material and Design}

Seeds of iceberg lettuce (Lactuca sativa var. capitata cv. Chianti) were sown on February $25^{\text {th }}$ and $24^{\text {th }}$ in 2018 and 2019 seasons, respectively, in polystyrene trays. After four weeks from sowing, lettuce seedlings were transplanted in open field, $30 \mathrm{~cm}$ apart on both sides of the ridge. In a strip plots design with three replicates, four fertilizer treatments (three organic fertilizers, i.e., biochar, compost and vermicompost in addition to mineral fertilizers) as well as three irrigation regimes $(60,80$ and $100 \%$ of crop evapotranspiration, ETc) were tested. The whole experimental plot size was $3.8 \mathrm{~m} \times 3.6 \mathrm{~m}$ with a net area of $10.5 \mathrm{~m}^{2}$, involving five ridges, $3.5 \mathrm{~m}$ length and $0.6 \mathrm{~m}$ width (Fig. 1).

\subsection{Organic Fertilizers Preparation}

Biochar According to Yu et al. (2013), the biochar was produced by heating air-dried tree branch clippings using slow pyrolysis for two hours (about $360-420^{\circ} \mathrm{C}$ ) in a pilot-scale 
Table 1 Meteorological data at Dokki Protected Cultivation Experimental Site, Egypt, during lettuce growing season of 2018 and 2019

\begin{tabular}{|c|c|c|c|c|c|c|c|c|}
\hline \multirow[t]{2}{*}{ Week } & \multicolumn{2}{|c|}{$\begin{array}{l}\text { Mean temperature } \\
\left({ }^{\circ} \mathrm{C}\right)\end{array}$} & \multicolumn{2}{|c|}{$\begin{array}{l}\text { Solar radiation } \\
\left(\mathrm{MJ} \mathrm{m}^{-2} \mathrm{day}^{-1}\right)\end{array}$} & \multicolumn{2}{|c|}{$\begin{array}{l}\text { Relative humidity } \\
(\%)\end{array}$} & \multicolumn{2}{|l|}{$\begin{array}{l}\text { Wind speed } \\
\left(\mathrm{m} \mathrm{s}^{-1}\right)\end{array}$} \\
\hline & 2018 & 2019 & 2018 & 2019 & 2018 & 2019 & 2018 & 2019 \\
\hline 1 & $14.1 \pm 0.1$ & $11.0 \pm 0.2$ & $20.1 \pm 0.3$ & $14.3 \pm 0.1$ & $52.5 \pm 0.6$ & $50.2 \pm 0.8$ & $3.17 \pm 0.18$ & $2.70 \pm 0.12$ \\
\hline 2 & $13.7 \pm 0.1$ & $11.0 \pm 0.1$ & $16.5 \pm 0.3$ & $12.2 \pm 0.1$ & $51.0 \pm 0.7$ & $49.0 \pm 0.7$ & $3.49 \pm 0.15$ & $2.36 \pm 0.13$ \\
\hline 3 & $15.7 \pm 0.2$ & $11.1 \pm 0.1$ & $20.3 \pm 0.2$ & $13.3 \pm 0.2$ & $47.3 \pm 0.6$ & $45.9 \pm 0.5$ & $2.49 \pm 0.18$ & $2.44 \pm 0.15$ \\
\hline 4 & $16.4 \pm 0.1$ & $12.1 \pm 0.2$ & $21.3 \pm 0.4$ & $15.8 \pm 0.3$ & $46.5 \pm 0.4$ & $43.7 \pm 0.6$ & $3.23 \pm 0.14$ & $1.98 \pm 0.12$ \\
\hline 5 & $13.9 \pm 0.2$ & $13.4 \pm 0.3$ & $23.0 \pm 0.2$ & $18.8 \pm 0.3$ & $48.6 \pm 0.6$ & $48.1 \pm 04$ & $3.31 \pm 0.19$ & $2.43 \pm 0.11$ \\
\hline 6 & $18.1 \pm 0.3$ & $14.6 \pm 0.4$ & $25.2 \pm 0.4$ & $15.7 \pm 0.2$ & $36.2 \pm 0.5$ & $34.1 \pm 0.8$ & $3.34 \pm 0.20$ & $3.40 \pm 0.17$ \\
\hline 7 & $20.5 \pm 0.3$ & $17.2 \pm 0.2$ & $22.8 \pm 0.2$ & $18.2 \pm 0.4$ & $31.5 \pm 0.3$ & $32.4 \pm 0.9$ & $3.10 \pm 0.13$ & $3.00 \pm 0.19$ \\
\hline 8 & $18.9 \pm 0.2$ & $16.8 \pm 0.3$ & $26.0 \pm 0.3$ & $21.6 \pm 0.2$ & $34.6 \pm 0.5$ & $35.1 \pm 0.4$ & $2.75 \pm 0.11$ & $2.74 \pm 0.16$ \\
\hline
\end{tabular}

The first week began on 25 and 24 March during 2018 and 2019 seasons, respectively. The meteorological data were obtained from Central Laboratory of Meteorology, Ministry of Agriculture and Land Reclamation, Egypt. Values are the mean of three replicates \pm standard errors
Table 2 Physico-chemical properties and water status of soil at Dokki Protected Cultivation Experimental Site, Egypt

\begin{tabular}{llc}
\hline Parameter & Unit & Value \\
\hline Mechanical analysis & & \\
Sand & $\%$ by weight & $16.9 \pm 0.1$ \\
Silt & $\%$ by weight & $30.8 \pm 0.2$ \\
Clay & $\%$ by weight & $52.3 \pm 0.4$ \\
Bulk density & $\mathrm{g} \mathrm{cm}^{-3}$ & $1.35 \pm 0.08$ \\
Chemical analysis & & \\
pH $(1: 2.5)$ & - & $7.64 \pm 0.06$ \\
Electrical conductivity $\left(\mathrm{EC}^{2}\right)$ & $\mathrm{dS} \mathrm{m}^{-1}$ & $2.69 \pm 0.02$ \\
Organic matter & $\mathrm{g} \mathrm{kg}^{-1}$ & $8.06 \pm 0.10$ \\
Available nitrogen & $\mathrm{mg} \mathrm{kg}^{-1}$ & $37.3 \pm 0.2$ \\
Available phosphorus & $\mathrm{mg} \mathrm{kg}^{-1}$ & $2.01 \pm 0.02$ \\
Available potassium & $\mathrm{mg} \mathrm{kg}^{-1}$ & $148.0 \pm 2.2$ \\
Calcium cations $\left(\mathrm{Ca}^{+2}\right)$ & $\mathrm{meq} \mathrm{L}^{-1}$ & $5.45 \pm 0.02$ \\
Magnesium cations $\left(\mathrm{Mg}^{+2}\right)$ & $\mathrm{meq} \mathrm{L}^{-1}$ & $3.87 \pm 0.03$ \\
Sodium cations $\left(\mathrm{Na}^{+}\right)$ & $\mathrm{meq} \mathrm{L}^{-1}$ & $11.60 \pm 1.05$ \\
Potassium cations $\left(\mathrm{K}^{+}\right)$ & $\mathrm{meq} \mathrm{L}^{-1}$ & $5.98 \pm 0.11$ \\
Chloride anions $\left(\mathrm{Cl}^{-}\right)$ & $\mathrm{meq} \mathrm{L}^{-1}$ & $12.9 \pm 0.52$ \\
Bicarbonate anions $\left(\mathrm{HCO}_{3}^{-}\right)$ & $\mathrm{meq} \mathrm{L}^{-1}$ & $7.05 \pm 0.10$ \\
Sulfate anions $\left(\mathrm{SO}_{4}^{-2}\right)$ & $\mathrm{meq} \mathrm{L}^{-1}$ & $6.95 \pm 0.1$ \\
Calcium carbonate $\left(\mathrm{CaCO}_{3}\right)$ & $\mathrm{g} \mathrm{kg}^{-1}$ & $56.1 \pm 0.6$ \\
Water status & & \\
Saturation percentage & $\%$ by volume & $87.9 \pm 2.0$ \\
Field capacity & $\%$ by volume & $62.1 \pm 1.4$ \\
Wilting point & $\% \mathrm{by} \mathrm{volume}^{-1}$ & $27.8 \pm 1.6$ \\
\hline
\end{tabular}

Carbonate anions $\left(\mathrm{CO}_{3}{ }^{-2}\right)$ were not detected. Values are the mean of three replicates \pm standard errors

electric pyrolizer. After cooling, the biochar was passed through a 2-mm sieve.
Compost The compost was prepared using the Indore method (Inckel et al. 2005). Briefly, the alternative layers of organic mixtures $(80 \%$ plant residues, i.e., cucumber, eggplant and tomato $+20 \%$ cattle manure) were used to make the compost pile $\left(1.25 \times 2.50 \times 0.75 \mathrm{~m}^{3}\right.$ in size $)$. A plastic sheet was used to cover the ground before making the pile to prevent nutrients solution leakage during watering the plant residues. Also, the pile was covered by clear plastic sheet to keep up the water content and to help in the decomposition process by increasing temperature. This process took approximately 4 months.

Vermicompost Processing involves collection of organic wastes. Pre-composting of organic waste (Nair et al. 2006; Frederickson et al. 2007) for ten days was done by mixing the organic material with cattle manure. This process partially digests the material and avoids the thermophilic stage. A layer of $15-20 \mathrm{~cm}$ of shredded newspaper kept as bedding material at the bottom of the bed. Beds of partially decomposed material of size $6 \times 2 \times 2$ feet were made. Earthworm (330-350 worms per $\mathrm{m}^{3}$ of bed volume; worm diameter $0.5-5 \mathrm{~mm}$ and worm length $10-120 \mathrm{~mm}$ ) were released in the upper layer of the bed. Water was sprinkled immediately after the release of worms. Every two days, beds were kept moist by sprinkling of water and turned for maintaining aeration.

Some chemical contents of biochar, compost and vermicompost are tabled (Table 3). The organic fertilizers were incorporated manually into the soil at the rate of 24 tons ha ${ }^{-1}$ during land preparation and before lettuce transplanting by one week. Regarding the mineral fertilizers (control treatment), the recommended NPK fertilizers were applied. Herein, ordinary superphosphate was added during land 


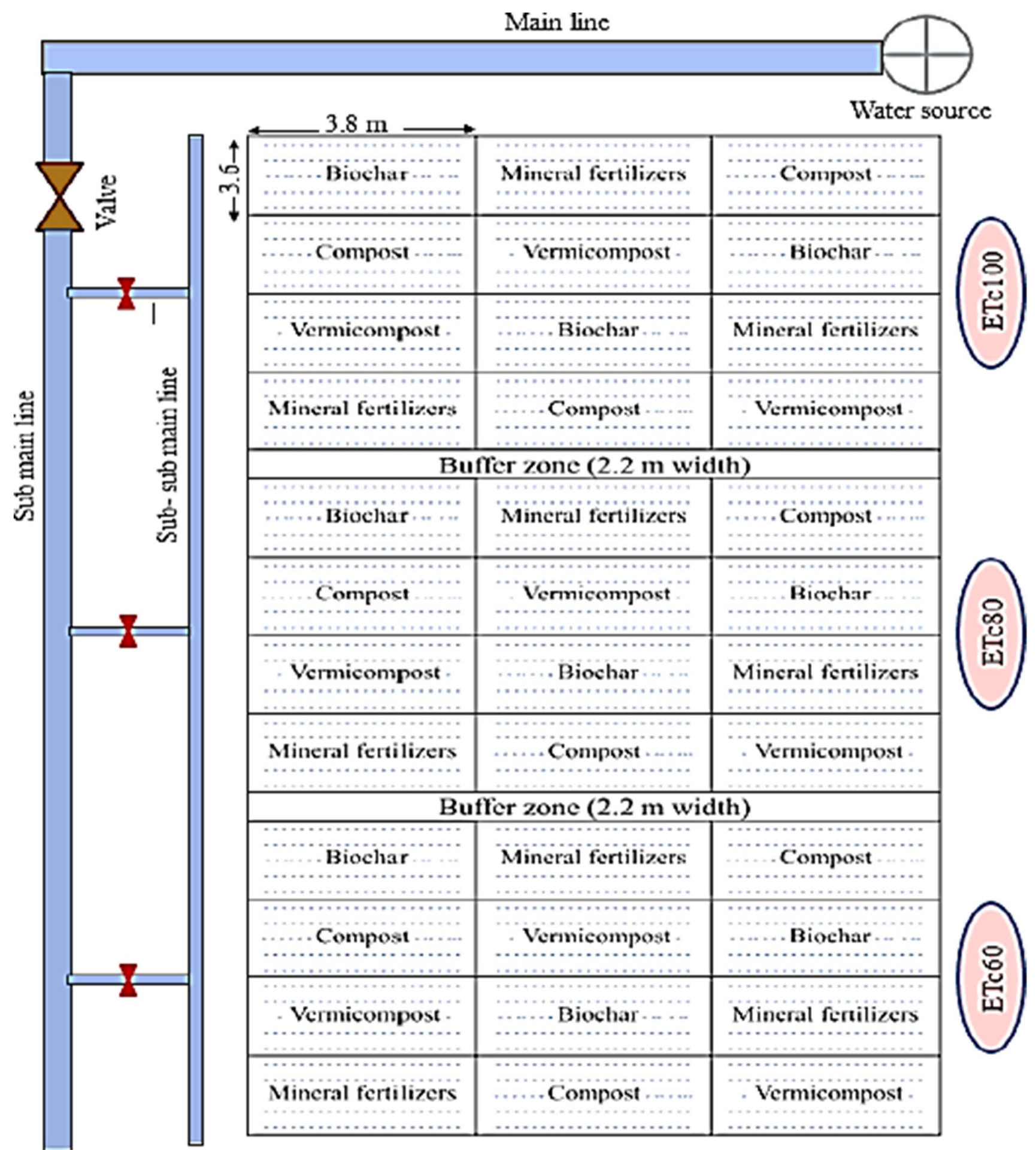

Fig. 1 Layout of the experiment with distribution of irrigation and fertilizer treatments. ETc60, ETc80 and ETc100 are irrigation by 60, 80 and $100 \%$ of crop evapotranspiration, respectively

preparation at a rate of $240 \mathrm{~kg} \mathrm{ha}^{-1}$. Ammonium sulfate $\left[\left(\mathrm{NH}_{4}\right)_{2} \mathrm{SO}_{4}\right]$ and potassium sulfate $\left(\mathrm{K}_{2} \mathrm{SO}_{4}\right)$ were added,
$360 \mathrm{~kg} \mathrm{ha}^{-1}$, for each, in two batches, 15 and 30 days after transplanting (DAT). 
Table 3 Some chemical contents of the tested organic fertilizers

\begin{tabular}{llllll}
\hline Organic fertilizer & \multicolumn{4}{l}{ Nutrient concentration $\left(\mathrm{mg} \mathrm{kg}^{-1}\right)$} & C/N ratio \\
\cline { 2 - 5 } & $\mathrm{N}$ & $\mathrm{P}$ & $\mathrm{K}$ & $\mathrm{C}$ & \\
\hline Biochar & $14600 \pm 100$ & $5100 \pm 200$ & $13800 \pm 700$ & $187000 \pm 1000$ & $12.8 \pm 0.02$ \\
Compost & $17300 \pm 200$ & $5500 \pm 300$ & $13100 \pm 300$ & $172000 \pm 1000$ & $9.94 \pm 0.06$ \\
Vermicompost & $17700 \pm 100$ & $7600 \pm 200$ & $15600 \pm 500$ & $178000 \pm 1000$ & $10.1 \pm 0.16$ \\
\hline
\end{tabular}

$\mathrm{N}$ : nitrogen, P: phosphorus, K: potassium, C: carbon. Values are the mean of three replicates \pm standard errors

\subsection{Water Requirements}

Irrigation water treatments were implemented as a ratio of the crop evapotranspiration (ETc) including irrigation by $60 \%$ (ETc60), 80\% (ETc80) and 100\% (ETc100) of ETc. Based on the meteorological data (Table 1), the daily ETo was calculated using Eq. 1 (Allen et al. 1998) as follows:

ETo $=\frac{0.408 \Delta\left(\mathrm{R}_{\mathrm{n}}-\mathrm{G}\right)+\gamma \frac{900}{\mathrm{~T}_{\text {mean }}+273} \mathrm{U}_{2}\left(\mathrm{e}_{\mathrm{s}}-\mathrm{e}_{\mathrm{a}}\right)}{\Delta+\gamma\left(1+0.34 \mathrm{U}_{2}\right)}$

where

ETo is reference evapotranspiration $\left(\mathrm{mm} \mathrm{day}^{-1}\right), \Delta$ is the slope of the saturation vapor pressure curve at air temperature $\left(\mathrm{kPa}^{\circ} \mathrm{C}^{-1}\right), \mathrm{R}_{\mathrm{n}}$ is net radiation at the crop surface (MJ $\mathrm{m}^{-2}$ day $\left.^{-1}\right), \mathrm{G}$ is soil heat flux density $\left(\mathrm{MJ} \mathrm{m}^{-2} \mathrm{day}^{-1}\right), \mathrm{T}$ is mean daily air temperature at $2 \mathrm{~m}$ height $\left({ }^{\circ} \mathrm{C}\right), \mathrm{U}_{2}$ is wind speed at $2 \mathrm{~m}$ height $\left(\mathrm{m} \mathrm{s}^{-1}\right), \mathrm{e}_{\mathrm{s}}$ is saturation vapor pressure $(\mathrm{kPa}), \mathrm{e}_{\mathrm{a}}$ is actual vapor pressure $(\mathrm{kPa}), \mathrm{e}_{\mathrm{s}}-\mathrm{e}_{\mathrm{a}}$ is saturation vapor pressure deficit $(\mathrm{kPa})$, and $\gamma$ is psychrometric constant $\left(\mathrm{kPa}^{\circ} \mathrm{C}^{-1}\right)$.

Using Eq. (2), the crop evapotranspiration (ETc) was measured. Then, the volume of irrigation water applied to each treatment during the irrigation event was determined by using Eq. 3 (Doorenbos and Pruitt 1984; Keller and Bliesner 1990) as follows:

$\mathrm{ETc}=\mathrm{ETo} \times \mathrm{Kc}$

where

ETc is crop evapotranspiration $\left(\mathrm{mm} \mathrm{day}^{-1}\right)$, ETo is reference evapotranspiration $\left(\mathrm{mm} \mathrm{day}^{-1}\right)$, and $\mathrm{Kc}$ is the crop coefficient as described by Allen et al. (1998).

$\mathrm{IWA}=\frac{\mathrm{A} \times \mathrm{ETc} \times \mathrm{Ii} \times \mathrm{Kr}}{\mathrm{Ea} \times 1000 \times(1-\mathrm{LR})}$

where

IWA is the irrigation water applied $\left(\mathrm{m}^{3}\right), \mathrm{A}$ is the plot area $\left(\mathrm{m}^{2}\right)$, ETc is the crop water requirements $\left(\mathrm{mm} \mathrm{day}^{-1}\right)$, $\mathrm{Ii}$ is the irrigation intervals (day), $\mathrm{Kr}$ covering factor, $\mathrm{Ea}$ is the application efficiency $(\%)(\mathrm{Ea}=85)$, and LR is the leaching requirements $\left(\mathrm{m}^{3}\right)$.

Accordingly, the gross seasonal irrigation water amounts based on irrigation treatments were about 2596,
3461 and $4327 \mathrm{~m}^{3} \mathrm{ha}^{-1}$ in 2018 season and 2486, 3314 and $4142 \mathrm{~m}^{3} \mathrm{ha}^{-1}$ in 2019 season with ETc60, ETc80 and ETc100, respectively.

Drip irrigation system was set up with 30.0-cm dripper spacing, and manufacturing dripper discharge $4.0 \mathrm{~L} \mathrm{hr}^{-1}$, at operating pressure of 1.0 bar. Flow meter was installed for each irrigation level treatment; boarders of two meters were left between different irrigation strips. Lettuce plants were irrigated every 2 days interval by different amounts of irrigation water applied according to the irrigation treatment.

\subsection{Assessments}

After lettuce harvest, soil samples were collected at the $0-15 \mathrm{~cm}$ depth. The collected samples were air-dried, crushed and sieved through a $2-\mathrm{mm}$ sieve and prepared to determine chemically available concentrations of nitrogen $(\mathrm{N})$, phosphorus $(\mathrm{P})$ and potassium $(\mathrm{K})$ as well as organic matter (OM) content in soil (Page et al. 1982). Moreover, samples of three plants of each experimental plot were taken at 55 days from transplanting date, to estimate head weight (lettuce yield ha ${ }^{-1}$ ). For mineral analysis of leaves, three plant samples of each plot were dried at $65^{\circ} \mathrm{C}$ in an air-forced oven for $48 \mathrm{~h}$. Dried leaves were digested by a mixture of $\mathrm{H}_{2} \mathrm{SO}_{4} / \mathrm{H}_{2} \mathrm{O}_{2}$ according to the method described by Chapman and Pratt (1961). Chemically available $\mathrm{N}$ in soil, and total $\mathrm{N}$ in plant were determined by microKjeldahl method using $5 \%$ boric acid and $40 \% \mathrm{NaOH}$ as described by Chapman and Pratt (1961). Nitrate was determined in the presence of Devarda's alloy and complete the same steps by micro-Kjeldahl method as described by Chapman and Pratt (1961). Phosphorus concentration was determined by ascorbic acid method using spectrophotometer according to Watanabe and Olsen (1965). Potassium concentration was determined using flame photometer as described by Chapman and Pratt (1961).

\subsection{Statistical Analysis}

Since the outputs proved that the homogeneity and normality of the data are satisfied for running analysis of variance 
(ANOVA), combined data of the two seasons were subjected to ANOVA according to Casella (2008), using Costat software program, Version 6.303, 2004. At $p \leq 0.05$ level of probability, Duncan's multiple range test was used for distinguishing among the treatment means.

\section{Results}

\subsection{Soil Analysis}

Despite nutrients and OM of soil decreased with increasing water amount, the differences among irrigation treatments were not significant, except $\mathrm{K}$ content (Table 4). Irrigation by ETc60 evenly with ETc 80 recorded the maximum $\mathrm{K}$ value.

Vermicompost was similar to biochar in increasing $\mathrm{N}$ and $\mathrm{K}$ soil content (Table 4). Moreover, P and OM showed the highest values with vermicompost, biochar or compost. On the contrary, mineral fertilizer treatment recorded the lowest $\mathrm{N}, \mathrm{P}, \mathrm{K}$ and $\mathrm{OM}$ contents.

Organic fertilizer resources (vermicompost, biochar or compost), under all irrigation regimes, were similar for recording the maximum increases in $\mathrm{N}, \mathrm{P}$ and $\mathrm{OM}$. Vermicompost and biochar (with any irrigation regime) as well as compost with irrigation by ETc60 were the effective combinations for increasing $\mathrm{K}$ content in soil (Table 4). In general, mineral fertilizer treatment caused higher reductions in $\mathrm{N}, \mathrm{P}, \mathrm{K}$ and $\mathrm{OM}$ contents under irrigation by ETc100, comparing to organic fertilizer treatments.

\subsection{Lettuce Yield and Plant Analysis}

Irrigation by ETc80 or ETc100 recorded 53.3 and $48.1 \%$ increases in lettuce yield, respectively, compared to ETc60 (Table 5). However, ETc60 gave the maximum values of plant nutrients content $\left(\mathrm{N}, \mathrm{P}, \mathrm{K}\right.$ and $\left.\mathrm{NO}_{3}-\mathrm{N}\right)$ and leveled ETc80 significantly in $\mathrm{P}$ and $\mathrm{NO}_{3}-\mathrm{N}$. Moreover, ETc80 was similar to ETc100 for recording low values of $\mathrm{N}$ and $\mathrm{NO}_{3}-\mathrm{N}$. The reduction \% in $\mathrm{NO}_{3}-\mathrm{N}$ accumulation due to ETc100 and ETc80 was 16.0 and $7.4 \%$ compared to ETc60.

The significant main effect of fertilization treatments showed that vermicompost and biochar caused increase in lettuce yield like that of mineral fertilizer (Table 5). Mineral fertilizer recorded the highest values of N, K
Table 4 Influence of irrigation (I) and fertilization (F) on nitrogen $(\mathrm{N})$, phosphorus $(\mathrm{P})$, potassium $(\mathrm{K})$ and organic matter (OM) of lettuce soil after harvest

\begin{tabular}{lllll}
\hline Variable & ETc60 & ETc80 & ETc100 & Mean \\
\hline Available N $\left(\mathrm{mg} \mathrm{kg}^{-1}\right)$ & & & & \\
Biochar & $72.7 \pm 6.8 \mathrm{a}$ & $72.6 \pm 3.9 \mathrm{a}$ & $64.4 \pm 3.6 \mathrm{abc}$ & $69.9 \pm 2.8 \mathrm{AB}$ \\
Compost & $64.7 \pm 3.8 \mathrm{abc}$ & $63.9 \pm 4.3 \mathrm{abc}$ & $58.7 \pm 5.3 \mathrm{abc}$ & $62.4 \pm 2.5 \mathrm{~B}$ \\
Vermicompost & $75.2 \pm 3.7 \mathrm{a}$ & $74.5 \pm 4.7 \mathrm{a}$ & $71.1 \pm 5.4 \mathrm{ab}$ & $73.6 \pm 3.1 \mathrm{~A}$ \\
Mineral fertilizer & $55.3 \pm 4.0 \mathrm{abc}$ & $52.2 \pm 5.1 \mathrm{bc}$ & $49.4 \pm 3.6 \mathrm{c}$ & $52.3 \pm 2.4 \mathrm{C}$ \\
Mean & $67.0 \pm 3.0 \mathrm{~A}$ & $65.8 \pm 2.8 \mathrm{~A}$ & $60.9 \pm 2.7 \mathrm{~A}$ & \\
Available P (mg kg & & & \\
Biochar & & & & $3.91 \pm 0.21 \mathrm{~A}$ \\
Compost & $4.15 \pm 0.44 \mathrm{ab}$ & $3.86 \pm 0.33 \mathrm{ab}$ & $3.73 \pm 0.30 \mathrm{ab}$ & $3.51 \pm 0.20 \mathrm{~A}$ \\
Vermicompost & $3.89 \pm 0.43 \mathrm{ab}$ & $3.37 \pm 0.21 \mathrm{ab}$ & $3.25 \pm 0.37 \mathrm{abc}$ & $4.15 \pm 0.20 \mathrm{~A}$ \\
Mineral fertilizer & $4.14 \pm 0.30 \mathrm{ab}$ & $4.40 \pm 0.48 \mathrm{a}$ & $3.91 \pm 0.26 \mathrm{ab}$ & $2.69 \pm 0.17 \mathrm{~B}$ \\
Mean & $3.07 \pm 0.30 \mathrm{bc}$ & $2.87 \pm 0.34 \mathrm{bc}$ & $2.14 \pm 0.12 \mathrm{c}$ & \\
Available K (mg kg & & & \\
Biochar & $3.81 \pm 0.19 \mathrm{~A}$ & $3.63 \pm 0.20 \mathrm{~A}$ & $3.25 \pm 0.19 \mathrm{~A}$ & \\
Compost & & & & \\
Vermicompost & $230.3 \pm 13.9 \mathrm{ab}$ & $212.0 \pm 18.4 \mathrm{abc}$ & $191.0 \pm 26.3 \mathrm{abc}$ & $211.1 \pm 11.6 \mathrm{AB}$ \\
Mineral fertilizer & $169.6 \pm 17.8 \mathrm{bcd}$ & $155.7 \pm 10.2 \mathrm{~cd}$ & $120.4 \pm 7.14 \mathrm{~d}$ & $148.6 \pm 8.4 \mathrm{C}$ \\
Mean & $215.4 \pm 11.7 \mathrm{~A}$ & $190.3 \pm 10.9 \mathrm{AB}$ & $173.8 \pm 10.4 \mathrm{~B}$ & \\
OM (g kg ${ }^{-1}$ ) & & & & $183.3 \pm 12.7 \mathrm{BC}$ \\
Biochar & $12.26 \pm 1.22 \mathrm{a}$ & $11.75 \pm 0.61 \mathrm{a}$ & $10.94 \pm 0.88 \mathrm{a}$ & $11.65 \pm 0.53 \mathrm{~A}$ \\
Compost & $12.31 \pm 0.71 \mathrm{a}$ & $10.82 \pm 1.11 \mathrm{a}$ & $10.27 \pm 0.79 \mathrm{ab}$ & $11.13 \pm 0.52 \mathrm{~A}$ \\
Vermicompost & $12.60 \pm 0.67 \mathrm{a}$ & $12.26 \pm 0.84 \mathrm{a}$ & $11.17 \pm 0.87 \mathrm{a}$ & $12.01 \pm 0.46 \mathrm{~A}$ \\
Mineral fertilizer & $8.09 \pm 0.57 \mathrm{bc}$ & $7.61 \pm 0.33 \mathrm{c}$ & $6.99 \pm 0.78 \mathrm{c}$ & $7.56 \pm 0.33 \mathrm{~B}$ \\
Mean & $11.31 \pm 0.55 \mathrm{~A}$ & $10.61 \pm 0.52 \mathrm{~A}$ & $9.84 \pm 0.52 \mathrm{~A}$ & \\
\hline & & & & \\
\hline
\end{tabular}

ETc60, ETc80 and ETc100: irrigation at 60, 80 and 100\% of crop evapotranspiration, respectively. Values are the mean of three replicates \pm standard errors. Varied letters within columns or rows indicates that there are significant differences by Duncan's multiple range test at $p \leq 0.05$ 
Table 5 Influence of irrigation (I) and fertilization (F) on yield, nitrogen $(\mathrm{N})$, phosphorus $(\mathrm{P})$, potassium $(\mathrm{K})$ and nitrate $\left(\mathrm{NO}_{3}-\mathrm{N}\right)$ of lettuce heads

\begin{tabular}{|c|c|c|c|c|}
\hline Variable & ETc60 & ETc80 & ETc100 & Mean \\
\hline \multicolumn{5}{|l|}{ Yield $\left(\mathrm{t} \mathrm{ha}^{-1}\right)$} \\
\hline Biochar & $20.6 \pm 1.9 \mathrm{ef}$ & $35.5 \pm 1.7 \mathrm{ab}$ & $33.9 \pm 2.5 \mathrm{ab}$ & $30.0 \pm 1.9 \mathrm{~A}$ \\
\hline Compost & $19.5 \pm 1.2 \mathrm{f}$ & $27.8 \pm 2.3 \mathrm{~cd}$ & $24.0 \pm 2.2 \mathrm{def}$ & $23.8 \pm 1.3 \mathrm{~B}$ \\
\hline Vermicompost & $25.6 \pm 2.0 \mathrm{cde}$ & $37.1 \pm 2.5 \mathrm{a}$ & $34.7 \pm 2.6 \mathrm{ab}$ & $32.5 \pm 1.7 \mathrm{~A}$ \\
\hline Mineral fertilizer & $19.7 \pm 1.0 \mathrm{f}$ & $30.6 \pm 2.3 b c$ & $34.1 \pm 1.9 \mathrm{ab}$ & $28.1 \pm 1.8 \mathrm{AB}$ \\
\hline Mean & $21.4 \pm 0.9 \mathrm{~B}$ & $32.8 \pm 1.3 \mathrm{~A}$ & $31.7 \pm 1.4 \mathrm{~A}$ & \\
\hline \multicolumn{5}{|l|}{$\mathrm{N}\left(\mathrm{mg} \mathrm{kg}^{-1}\right)$} \\
\hline Biochar & $25612 \pm 1272 b$ & $21252 \pm 1358 \mathrm{bcd}$ & $19901 \pm 879 d$ & $22255 \pm 874 \mathrm{~B}$ \\
\hline Compost & $24358 \pm 1082 b c$ & $20454 \pm 869 \mathrm{~cd}$ & $19703 \pm 1244 d$ & $21505 \pm 765 B$ \\
\hline Vermicompost & $25095 \pm 1648 b$ & $22448 \pm 1094 \mathrm{bcd}$ & $20459 \pm 839 \mathrm{~cd}$ & $22667 \pm 815 B$ \\
\hline Mineral fertilizer & $30461 \pm 1026 a$ & $24752 \pm 1628 b c$ & $21349 \pm 790 \mathrm{bcd}$ & $25520 \pm 1120 \mathrm{~A}$ \\
\hline Mean & $26381 \pm 778 \mathrm{~A}$ & $22227 \pm 464 B$ & $20353 \pm 464 B$ & \\
\hline \multicolumn{5}{|l|}{$\mathrm{P}\left(\mathrm{mg} \mathrm{kg}^{-1}\right)$} \\
\hline Biochar & $7482 \pm 37 \mathrm{abcd}$ & $6953 \pm 37 \mathrm{bcdef}$ & $5712 \pm 57 \mathrm{ef}$ & $6715 \pm 30 \mathrm{AB}$ \\
\hline Compost & $7065 \pm 32 \mathrm{bcde}$ & $6411 \pm 43 \mathrm{def}$ & $5483 \pm 41 \mathrm{f}$ & $6319 \pm 27 B$ \\
\hline Vermicompost & $8261 \pm 38 \mathrm{ab}$ & $7174 \pm 41 \mathrm{bcde}$ & $6221 \pm 46 \mathrm{def}$ & $7218 \pm 30 \mathrm{AB}$ \\
\hline Mineral fertilizer & $8661 \pm 39 a$ & $8091 \pm 45 a b c$ & $6632 \pm 72 \mathrm{cdef}$ & $7794 \pm 33 \mathrm{~A}$ \\
\hline Mean & $7867 \pm 21 \mathrm{~A}$ & $7157 \pm 23 \mathrm{~A}$ & $6012 \pm 28 \mathrm{~B}$ & \\
\hline \multicolumn{5}{|l|}{$\mathrm{K}\left(\mathrm{mg} \mathrm{kg}^{-1}\right)$} \\
\hline Biochar & $16403 \pm 692 b c$ & $13504 \pm 664 d e$ & $12009 \pm 540 \mathrm{e}$ & $13972 \pm 560 \mathrm{C}$ \\
\hline Compost & $15002 \pm 454 \mathrm{~cd}$ & $12250 \pm 640 \mathrm{e}$ & $9898 \pm 412 f$ & $12383 \pm 577 \mathrm{D}$ \\
\hline Vermicompost & $18003 \pm 679 a b$ & $15001 \pm 990 \mathrm{~cd}$ & $12505 \pm 729 \mathrm{e}$ & $15170 \pm 700 \mathrm{~B}$ \\
\hline Mineral fertilizer & $19252 \pm 738 \mathrm{a}$ & $16696 \pm 811 b c$ & $12955 \pm 365 \mathrm{e}$ & $16301 \pm 724 \mathrm{~A}$ \\
\hline Mean & $17165 \pm 452 \mathrm{~A}$ & $14363 \pm 505 B$ & $11842 \pm 347 \mathrm{C}$ & \\
\hline \multicolumn{5}{|l|}{$\mathrm{NO}_{3}{ }^{-} \mathrm{N}\left(\mathrm{mg} \mathrm{kg}^{-1}\right)$} \\
\hline Biochar & $724.0 \pm 43.2 \mathrm{~cd}$ & $701.9 \pm 50.2 \mathrm{cde}$ & $646.8 \pm 32.9 \mathrm{def}$ & $690.9 \pm 24.4 B$ \\
\hline Compost & $648.0 \pm 30.0 \mathrm{def}$ & $596.8 \pm 38.0 \mathrm{ef}$ & $531.5 \pm 36.2 \mathrm{f}$ & $592.1 \pm 22.2 \mathrm{C}$ \\
\hline Vermicompost & $815.1 \pm 47.0 \mathrm{bc}$ & $757.5 \pm 33.8 \mathrm{bcd}$ & $697.9 \pm 41.5 \mathrm{cde}$ & $756.8 \pm 25.1 B$ \\
\hline Mineral fertilizer & $940.8 \pm 62.1 \mathrm{a}$ & $839.0 \pm 44.8 \mathrm{ab}$ & $751.6 \pm 38.2 \mathrm{bcd}$ & $843.8 \pm 32.7 \mathrm{~A}$ \\
\hline Mean & $782.0 \pm 31.6 \mathrm{~A}$ & $723.8 \pm 26.9 \mathrm{AB}$ & $657.0 \pm 24.3 \mathrm{~B}$ & \\
\hline
\end{tabular}

ETc60, ETc80 and ETc100: irrigation at 60, 80 and 100\% of crop evapotranspiration, respectively. Values are the mean of three replicates \pm standard errors. Varied letters within columns or rows indicates that there are significant differences by Duncan's multiple range test at $p \leq 0.05$ and $\mathrm{NO}_{3}-\mathrm{N}$ and exceeded all organic fertilizer forms in this respect. Moreover, $\mathrm{P}$ values of vermicompost or biochar were similar to that of mineral fertilizer treatment. Accumulation of $\mathrm{K}$ and $\mathrm{NO}_{3}-\mathrm{N}$ in lettuce leaves was low with the use of compost. It should be noted that $\mathrm{NO}_{3}-\mathrm{N}$ accumulation in lettuce leaves was less with organic fertilizers application (Table 5). The accumulation rates of $\mathrm{NO}_{3}{ }^{-} \mathrm{N}$ owing to biochar, compost and vermicompost were $18.1,29.8$ and $10.3 \%$ lower than mineral fertilizer.

Vermicompost and biochar x ETc80 or ETc100 were the efficient treatments for boosting lettuce yield and equaled the mineral fertilizer x ETc100 treatment (Table 5). Irrigation by ETc60 x mineral fertilizer showed the highest values of N, P, K and $\mathrm{NO}_{3}-\mathrm{N}$, and leveled with ETc60 $\mathrm{x}$ vermicompost in $\mathrm{P}$ and $\mathrm{K}$ content as well as irrigation by ETc80 x mineral fertilizer in $\mathrm{NO}_{3}-\mathrm{N}$ content.
As shown in Table 5, the higher values of $\mathrm{NO}_{3}-\mathrm{N}$ accumulation were recorded with ETc60 x mineral fertilizer. While the accumulation rates of $\mathrm{NO}_{3}-\mathrm{N}$ were less with using the different organic fertilizers under different irrigation regimes (Table 5). In this regard, compost x ETc80 or ETc100 showed the minimal $\mathrm{NO}_{3}-\mathrm{N}$ accumulation, hence, high relative reductions in $\mathrm{NO}_{3}-\mathrm{N}$ accumulation as compared to the common practice (mineral fertilizer x ETc100) were observed (Fig. 2).

\section{Discussion}

Results of the current research showed that the combinations of irrigation pattern plus fertilizer type have a distinctive role for changing the nutrient balance in soil in favor of crop growth. Findings showed that available $\mathrm{K}$ in lettuce soil after harvest was the most affected element by irrigation 
Fig. 2 Reduction \% in nitrate accumulation in lettuce as affected by organic fertilizers under different irrigation regimes relative to the common practice (mineral fertilizer $\mathrm{x}$ ETc100). ETc60, ETc80 and ETc100: irrigation at 60,80 and $100 \%$ of crop evapotranspiration, respectively. Values are the mean of three replicates \pm standard errors. Bars with different letters are statistically significant at $p \leq 0.05$

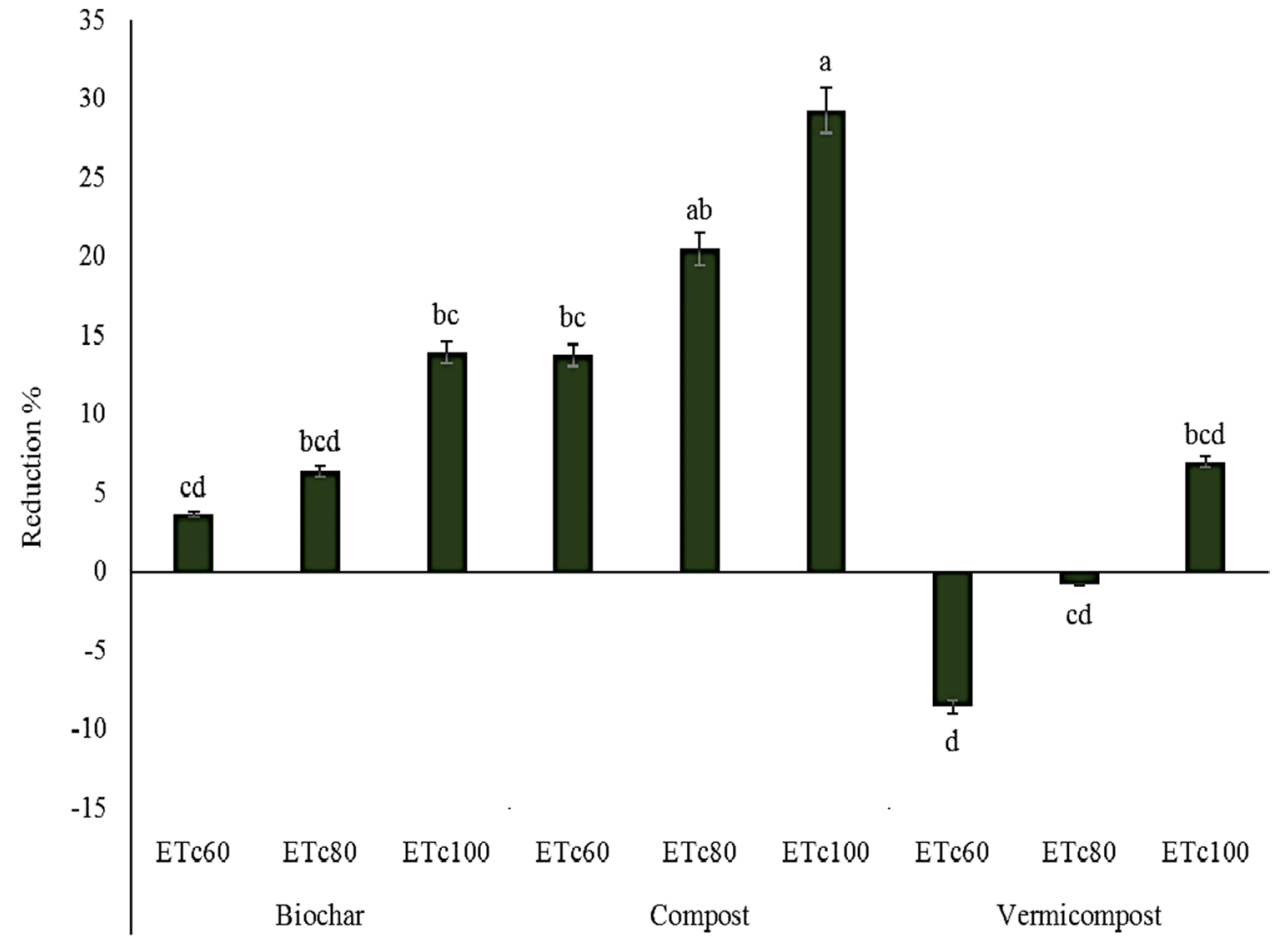

Irrigation regime $\mathrm{x}$ organic fertilizer treatments, since limited accumulation in $\mathrm{K}$ was obtained with high irrigation level (ETc100). This result might be due to increasing leaching process with water abundance. The higher the water depth, the larger the percolated amount of the $\mathrm{K}^{+}$ion (Mendes et al. 2016).

Organic fertilizers preserved nutrients and enhanced organic matter content in soil comparing to mineral ones. After harvesting of lettuce crop, soil analysis detected the loss of soil nutrients and limitation of OM with application of mineral fertilizer treatment compared to organic ones (Table 4). This event was more evident with increasing irrigation water amount, since mineral fertilizer treatment x ETc100 caused higher limitations in N, P, K and OM content. In this context, Hepperly et al. (2009) reported that the continuous application of chemical fertilizers led to depression in soil properties and crop yields by time. Under nutrient deficiency conditions, farmers add a large amount of mineral fertilizers to ensure high yields (Agostini et al. 2010). However, a large quantity of $\mathrm{N}$ might be leached into groundwater and increase the contamination of water.

In addition to overdone fertilization, overdone irrigation is another common agricultural habit needed to be concerned (Liang et al. 2014). Excessive irrigation combined with excessive fertilization could easily lead to nutrient leaching issues, and then groundwater pollution (Thompson et al. 2007; Shi et al. 2009). On the other hand, some organic fertilizers use can modify soil physicochemical conditions owing to their richness of organic matter and nutrients (Bhattacharyya et al. 2007; Sun et al. 2015). Also, Rutkowska et al. (2014) stated that long-term application of organic fertilizers can alter soil characteristics (e.g., pH and microorganisms) and therefore lead to soil richness in available forms of macronutrients. Moreover, variation in nutrient concentrations in soil after harvesting lettuce due to various organic fertilizers (vermicompost, biochar or compost) could be attributed to the difference in degree and rate of mineralization processes in soil as well as their organic carbon content. In this situation, the changes in applied organic fertilizer and released N, K and $\mathrm{Ca}$ in soil are relaying on the manure type and soil traits (Hernández et al. 2016). Furthermore, organic fertilizers have soil microbial content and activity higher than chemical fertilizers (El-Mogy et al. 2020). These findings might be linked with the amounts of organic carbon in various organic fertilizers (Chakraborty et al. 2011; Amalraj et al. 2013). Since organic manures, i.e., vermicomposts have minerals in available forms (Table 3), enhancement of soil quality and nutrient availability to the plants were achieved (Birkhofer et al. 2008; Yang et al. 2015).

Efficient water and fertilizer management have been increasingly adopted in crop production. With using moderate deficit irrigation ( $90 \%$ of evapotranspiration), a reduction of $\mathrm{N}$ fertilizer input did not suppress crop yield, but increased water and $\mathrm{N}$ fertilizer use efficiencies (Cabello 
et al. 2009). In this respect, the inappropriate soil water supply (too much or too little water) not only affects soil biological activities and soil properties (Salem et al. 2021), but also affects crop growth and productivity (El-Bially et al. 2018; El-Metwally and Saudy 2021). Since irrigation by ETc 80 was similar to ETc100 and better than ETc60 for recording high lettuce yield (Table 5), this may refer to achieving a better soil nutrient balance under moderate irrigation $(\mathrm{ETc} 80)$ in lettuce. With adequate soil water supply, high soil enzyme and microbial activities and oxygen conditions were obtained (Borowik and Wyszkowska 2016). Unlike, lowering water supply by $40 \%$ (ETc60) of normal (ETc100) could negatively influence the properties of the soil. In keeping with this trend, Mubarak et al. (2021) have reported that irrigation by $60 \%$ of crop evapotranspiration showed reduction in organic matter and carbon and soil activity. Due to the importance of water in promoting soil enzymes produced by microorganisms, water deficiency caused adverse impact on biological activity of soil biota (Hueso et al. 2012) and disturbance in the balance of nutrients soil and plant (Kim et al. 2008; Saudy and El-Metwally 2019). Undoubtedly, imbalance of elements in the soil will negatively affect the growth of the crop. In addition, drought had negative impacts on plant physiological and growth and eventually resulted in low economic yield (Saudy et al. 2021). Therefore, remarkable reduction in lettuce yield was observed owing to deficit water, i.e., irrigation by $60 \%$ of crop evapotranspiration (Table 5). These findings are in harmony with those obtained by Zhou et al. (2014) who found that water stress lowered dry matter and photosynthetic efficiency in lettuce.

Concerning lettuce chemical composition, in general, higher values of nutrient content in lettuce were produced with low water supply (ETc60), especially $\mathrm{N}$ and $\mathrm{K}$ content (Table 5). Compared to high water supply, low water supply lowered the rate of $\mathrm{N}$ leaching from soil, since water or nutrient solution was kept around the roots in the upper soil zone for a longer period (Tafteh and Sepaskhah 2012). Increasing irrigation water amount during crop growth stages could increase the nutrient leachates owing to the dilution effect of water (Hashem et al. 2014; Hashem and Abd-Elrahman 2016), and consequently reduces the availability of nutrients to crop plants that needed to be absorbed.

As for the effect of organic fertilization on lettuce crop, since vermicompost, biochar or compost improved the soil nutrient status (Table 4), improvements in lettuce yield and quality were occurred (Table 5). Since some organic fertilizing sources influence soil physical properties as well as soil microbial activity (Cayuela et al. 2009; Lima et al. 2009), the application of organic fertilizers improved crop productivity greater than the chemical fertilizers (Wassie 2012). Further studies pointed out that application of slow-release nitrogen fertilizer (organic) produced lettuce yield greater than mineral nitrogen fertilizer (Yeshiwas et al. 2018).

With moderate irrigation water supply, the action of organic fertilizers is more important, since irrigating the organically fertilized lettuce by $80 \%$ of crop evapotranspiration enhanced the lettuce yield (Table 5) with saving 20\% of irrigation water. It has been demonstrated that increased application of organic fertilizer (manure) could decrease the amount of leachate (Girotto et al. 2013), due to the enhanced water-holding capacity by organic fertilizer, while inorganic fertilizer may not influence soil water-holding capacity ( $\mathrm{Li}$ et al. 2018).

The use of slow-release fertilizers or organic manure gave high yield with low nitrate content in the leaves and decreased the loss of nitrogen into the water table, since they delayed the transformation of $\mathrm{N}$ into nitrate (El-Shinaway et al. 1999). Nazaryuk et al. (2002) mentioned that the poorly controlled flux of soil nitrogen resulting from active mineralization of organic matter may lead to excessive accumulation of nitrate in plants. Accordingly, accumulation of $\mathrm{NO}_{3}-\mathrm{N}$ of mineral fertilizer treatment reached about 1.24 times than organic fertilizers (Table 5). Also, lower rate of transforming $\mathrm{N}$ to $\mathrm{NO}_{3}-\mathrm{N}$ was observed with compost (Fig. 2).

\section{Conclusions}

Findings of the current research indicated that irrigating lettuce by $80 \%$ of crop evapotranspiration achieved yield and nutritional value like the full irrigation (100\%). Accumulation of nitrate in lettuce leaves was higher with the application of mineral fertilizers than organic ones. Hence, application of compost with irrigation by $80 \%$ of crop evapotranspiration showed promising solution to reduce the accumulation of nitrate in lettuce. The equilibrium between soil water and soil nutrition can be achieved by irrigating the organically fertilized lettuce using $80 \%$ of crop evapotranspiration instead of $100 \%$. Also, it is obvious that dispensing with mineral fertilizers and substituting them with vermicompost or biochar can be applied in the fertilization program for higher productivity of lettuce.

Acknowledgements The authors acknowledge the technical support provided by Faculty of Agriculture, Ain Shams University and Central Laboratory for Agricultural Climate, Agricultural Research Center, Egypt.

Funding Open access funding provided by The Science, Technology \& Innovation Funding Authority (STDF) in cooperation with The Egyptian Knowledge Bank (EKB). 


\section{Declarations}

Disclosure Statement The authors declare that they have no conflict of interests concerning the current research publication.

Open Access This article is licensed under a Creative Commons Attribution 4.0 International License, which permits use, sharing, adaptation, distribution and reproduction in any medium or format, as long as you give appropriate credit to the original author(s) and the source, provide a link to the Creative Commons licence, and indicate if changes were made. The images or other third party material in this article are included in the article's Creative Commons licence, unless indicated otherwise in a credit line to the material. If material is not included in the article's Creative Commons licence and your intended use is not permitted by statutory regulation or exceeds the permitted use, you will need to obtain permission directly from the copyright holder. To view a copy of this licence, visit http://creativecommons.org/licenses/by/4.0/.

\section{References}

Abul-Soud MA, Emam MSA, Abdrabbo MAA, Hashem FA, AbdElrahman Shaimaa H (2014) Sustainable urban horticulture of sweet pepper via vermicomposting in summer season. J Adv Agric $3: 110-122$

Agostini F, Tei F, Silgram M, Farneselli M, Benincasa P, Aler MF (2010) Decreasing nitrate leaching in vegetable crops with better $\mathrm{N}$ management. In: Lichtfouse $\mathrm{E}$ (ed) Genetic engineering, biofertilisation, soil quality and organic farming. Springer, Netherland. https://doi.org/10.1007/2F978-90-481-8741-6_6

Allen RG, Pereira LS, Raes D, Smith M (1998) Crop evapotranspiration-Guidelines for computing crop water requirements-FAO Irrigation and drainage paper 56. FAO-Food and Agriculture Organization of the United Nations, Rome

Amalraj ELD, Kumar GP, Ahmed SKMH, Abdul R, Kishore N (2013) Microbiological analysis of Panchagavya, vermicompost, and FYM and their effect on plant growth promotion of pigeon pea (Cajanus cajan L.) in India. Org Agric 3:23-29. https://doi.org/ 10.1007/s13165-013-0042-2

Bhargava S, Sawant K (2013) Drought stress adaptation: metabolic adjustment and regulation of gene expression. Plant Breed 132:21-32. https://doi.org/10.1111/pbr.12004

Bhattacharyya R, Chandra S, Singh RD, Kundu S (2007) Long-term farmyard manure application effects on properties of a silty clay loam soil under irrigated wheat-soybean rotation. Soil till Res 94:386-396. https://doi.org/10.1016/j.still.2006.08.014

Birkhofer K, Bezemer TM, Bloem J, Bonkowski M, Christensen S, Dubois D, Ekelund F, Fließach A, Gunst L, Hedlund K, Mäder P, Mikola J, Robin C, Setälä H, Tatin-Froux F, Van Der Putten WH, Scheu S (2008) Long-term organic farming fosters below and aboveground biota: implications for soil quality, biological control and productivity. Soil Biol Biochem 40:2297-2308. https://doi. org/10.1016/j.soilbio.2008.05.007

Boroujerdnia M, Ansari NA, Dehcordie FS (2007) Effect of cultivars, harvesting time and level of nitrogen fertilizer on nitrate and nitrite content, yield in Romaine lettuce. Asian J Plant Sci 6:550-553. https://scialert.net/abstract/?doi=ajps.2007.550.553

Borowik A, Wyszkowska J (2016) Soil moisture as a factor affecting the microbiological and biochemical activity of soil. Plant Soil Environ 62:250-255. https://doi.org/10.17221/158/2016-PSE
Bozkurt S, Mansurolu GS, Kara M, Önder S (2009) Responses of lettuce to irrigation levels and nitrogen forms. Afr J Agric Res 4:1171-1177

Cabello MJ, Castellanos MT, Romojaro F, Martinez-Madrid C, Ribas F (2009) Yield and quality of melon grown under different irrigation and nitrogen rates. Agric Wat Manage 96:866-874. https:// doi.org/10.1016/j.agwat.2008.11.006

Caliskan S, Yetisir H, Karanlik S (2014) Combined use of green manure and farmyard manure allows better nutrition of organic lettuce. Notulae Botanicae Horti Agrobotanici Cluj-Napoca 42:248-254. https://doi.org/10.15835/nbha4219328

Casella G (2008) Statistical Design, $1^{\text {st }}$ edn. Springer, Gainesville

Cayuela ML, Sinicco T, Mondini C (2009) Mineralization dynamics and biochemical properties during initial decomposition of plant and animal residues in soil. App Soil Ecol 41:118-127. https:// doi.org/10.1016/j.apsoil.2008.10.001

Cercioglu M, Okur B, Delibacak S, Ongun AR (2012) Effects of tobacco waste and farmyard manure on soil properties and yield of lettuce (Lactuca sativa L. var. capitata). Comm Soil Sci Plant Anal 43:875-886. https://doi.org/10.1080/00103624.2012.653023

Chakraborty A, Chakrabarti K, Chakraborty A, Ghosh S (2011) Effect of long-term fertilizers and manure application on microbial biomass and microbial activity of a tropical agricultural soil. Biol Fertil Soils 47:227-233. https://doi.org/10.1007/ s00374-010-0509-1

Chapman HD, Pratt PF (1961) Methods of analysis for soils, plants and waters. California, Division of Agric. Sci., Berkeley Univ, USA, pp 150-152

Chaves M, Flexas J, Pinheiro C (2009) Photosynthesis under drought and salt stress: regulation mechanisms from whole plant to cell. Ann Bot 103:551-560. https://doi.org/10.1093/aob/mcn125

Doorenbos J, Pruitt WO (1984) Guidelines for predicting crop water requirements irrigation and drainage Paper 24. FAO, Rome, p 348

El-Bially MA, Saudy HS, El-Metwally IM, Shahin MG (2018) Efficacy of ascorbic acid as a cofactor for alleviating water deficit impacts and enhancing sunflower yield and irrigation water-use efficiency. Agric Water Manage 208:132-139. https://doi.org/10. 1016/j.agwat.2018.06.016

El-Metwally IM, Saudy HS (2021) Interactional impacts of drought and weed stresses on nutritional status of seeds and water use efficiency of peanut plants grown in arid conditions. Gesunde Pflanzen 73:407-416. https://doi.org/10.1007/ s10343-021-00557-3

El-Metwally IM, Saudy HS, Abdelhamid MT (2021) Efficacy of benzyladenine for compensating the reduction in soybean productivity under low water supply. Italian J Agromet 2:81-90. https://doi. org/10.36253/ijam-872

El-Metwally IM, Geries L, Saudy HS (2022) Interactive effect of soil mulching and irrigation regime on yield, irrigation water use efficiency and weeds of trickle-irrigated onion. Archiv Agron Soil Sci. https://doi.org/10.1080/03650340.2020.1869723

El-Mogy M, Abdelaziz SM, Mahmoud AWM, Elsayed TR, AbdelKader NH, Mohamed MIA (2020) Comparative effects of different organic and inorganic fertilizers on soil fertility, plant growth, soil microbial community, and storage ability of lettuce. Agric (Pol'nohospodárstvo) 66:87-107. https://doi.org/10.2478/ agri-2020-0009

El-Shinaway MZ, Abd-Elmoniem EM, Abou-Hadid AF (1999) The use of organic manure for lettuce plants grown under NET conditions. Acta Hort 491:315-318. https://doi.org/10.17660/ActaH ortic.1999.491.47

Frederickson J, Howell G, Hobson AM (2007) Effect of pre-composting and vermicomposting on compost characteristics. Eur J Soil Biol 43:S320-S326. https://doi.org/10.1016/j.ejsobi.2007.08.032

Girotto E, Ceretta CA, Lourenzi CR, Lorensini F, Tiecher TL, Vieira RCB, Trentin G, Basso CJ, Miotto A, Brunetto G (2013) Nutrient 
transfers by leaching in a no-tillage system through soil treated with repeated pig slurry applications. Nutr Cycl Agroecosyst 95:115-131. https://doi.org/10.1007/s10705-013-9552-2

Hashem FA, Abd-Elrahman SH (2016) Soil chemical characteristics and growth of broccoli and cauliflower plants as affected by liquid organic fertilizers and irrigation water levels. Glob J Adv Res 3:881-895

Hashem FA, Abdrabbo MAA, Abou-El-Hassan S, Abul-Soud MA (2014) Maximizing water use efficiency via different organic mulches and irrigation levels. Res J Agric Biol Sci 10:109-117. http://www.aensiweb.net/AENSIWEB/rjabs/rjabs/2014/109-117. pdf

Hepperly YP, Lotter D, Ulsh CZ, Siedel R, Reider C (2009) Compost, manure and synthetic fertilizer influences crop yields, soil properties, nitrate leaching and crop nutrient content. Compost Sci Util 17:117-126. https://doi.org/10.1080/1065657X.2009.10702410

Hernández T, Chocano C, Moreno JL, García C (2016) Use of compost as an alternative to conventional inorganic fertilizers in intensive lettuce (Lactuca sativa L.) crops-effects on soil and plant. Soil till Res 160:14-22. https://doi.org/10.1016/j.still.2016.02.005

Hoque MM, Ajwa H, Othman Mona (2010) Yield and postharvest quality of lettuce in response to nitrogen, phosphorus, and potassium fertilizers. Hort Sci 45:1539-1544. https://doi.org/10.21273/ HORTSCI.45.10.1539

Hueso S, García C, Hernández T (2012) Severe drought conditions modify the microbial community structure, size and activity in amended and unamended soils. Soil Biol Biochem 50:167-173. https://doi.org/10.1016/j.soilbio.2012.03.026

Inckel M, Smet PD, Tersmette T, Veldkamp T (2005) The preparation and use of compost. Agromisa Foundation, Wageningen. Digigrafi, Wageningen, The Netherland. p 22-24

Keller J, Bliesner RD (1990) Sprinkle and trickle irrigation. Van Nostr and Reinhold New York, New York, p 22

Kim SY, Lee SH, Freeman C, Fenner N, Kang H (2008) Comparative analysis of soil microbial communities and their responses to the short-term drought in bog, fen, and riparian wetlands. Soil Biol Biochem 40:2874-2880. https://doi.org/10.1016/j.soilbio.2008. 08.004

Kim MJ, Moon Y, Tou JC, Mou B, Waterland NL (2016) Nutritional value, bioactive compounds and health benefits of lettuce ( $\mathrm{Lac}$ tuca sativa L.). J Food Compos Anal 49:19-34. https://doi.org/ 10.1016/j.jfca.2016.03.004

Klute A (1986) Methods of Soil Analysis, part I, $2^{\text {nd }}$ ed., USA: Madison, Wisconsin, p 1188

Kmecl V, Knap T, Žnidarčič D (2017) Evaluation of the nitrate and nitrite content of vegetables commonly grown in Slovenia. Ital J Agron 12:79-84. https://doi.org/10.4081/ija.2017.801

Koyama R, Itoh H, Kimura S, Mirioka A, Uno Y (2012) Augmentation of antioxidant constituents by drought stress to roots in leafy vegetables. Hort Technol 22:121-125. https://doi.org/10.21273/ HORTTECH.22.1.121

Křístková E, Doležalová I, Lebeda A, Vinter V, Novotná A (2008) Description of morphological characters of lettuce (Lactuca sativa L.) genetic resources. Hort Sci 35:113-129. https://doi.org/10. 17221/4/2008-HORTSCI

Laxa M, Liebthal M, Telman W, Chibani K, Dietz KJ (2019) The role of the plant antioxidant system in drought tolerance. Antioxidants 8:94. https://doi.org/10.3390/2Fantiox8040094

Li Y, Li J, Gao L, Tian Y (2018) Irrigation has more influence than fertilization on leaching water quality and the potential environmental risk in excessively fertilized vegetable soils. PLoS ONE 13:e0204570. https://doi.org/10.1371/journal.pone.0204570

Liang XS, Gao YN, Zhang XY, Tian YQ, Zhang ZX, Gao LH (2014) Effect of optimal daily fertigation on migration of water and salt in soil, root growth and fruit yield of cucumber (Cucumis sativus
L.) in solar-greenhouse. PloS ONE 9:e86975. https://doi.org/10. 1371/journal.pone.0086975

Lima DLD, Santos SM, Scherer HW, Schneider RJ, Duarte AC, Santos EBH, Esteves VI (2009) Effects of organic and inorganic amendments on soil organic matter properties. Geoderma 150:38-45. https://doi.org/10.1016/j.geoderma.2009.01.009

Lone AH, Najar GR, Ganie MA, Sofi JA, Tahir A (2015) Biochar for sustainable soil health: A review of prospects and concerns. Pedosphere 25:639-653. https://doi.org/10.1016/S1002-0160(15) 30045-X

Makhlouf BSI, Khalil Soha RA, Saudy HS (2022) Efficacy of humic acids and chitosan for enhancing yield and sugar quality of sugar beet under moderate and severe drought. J Soil Sci Plant Nutr. https://doi.org/10.1007/s42729-022-00762-7

Maynard DN, Hochmuth GJ (2007) Knott's handbook for vegetable growers, $5^{\text {th }}$ edn. John Wiley and Sons, Hoboken, p 250 (ISBN-13 978-0-471-73828-2)

Mendes WC, Júnior JA, da Cunha PCR, da Silva AR, Evangelista AWP, Casaroli D (2016) Potassium leaching in different soils as a function of irrigation depths. Revista Brasileira de Engenharia Agrícola e Ambiental 20:972-977. https://doi.org/10.1590/1807-1929/ agriambi.v20n11p972-977

Moreira MA, dos-Santos CAP, Lucas AAT, Bianchini FG, de-Souza IM, Viégas PRA (2014) Lettuce production according to different sources of organic matter and soil cover. Agric Sci 5:99-105. https://doi.org/10.4236/as.2014.52013

Mostafa HHA, Hefzy M, Zahran MMAA, Refai EFS (2019) Response of lettuce (Lactuca sativa L.) plants to application of compost levels under various irrigation regimes. Mid East J Agric Res $8: 662-674$

Mubarak M, Salem EMM, Kenawey MKM, Saudy HS (2021) Changes in calcareous soil activity, nutrient availability, and corn productivity due to the integrated effect of straw mulch and irrigation regimes. J Soil Sci Plant Nutr 21:2020-2031. https://doi.org/10. 1007/s42729-021-00498-w

Munné-Bosch S, Peñuelas J (2003) Photo-and antioxidative protection, and a role for salicylic acid during drought and recovery in field-grown Phillyrea angustifolia plants. Planta 217:758-766. https://doi.org/10.1007/s00425-003-1037-0

Nair J, Sekiozoic V, Anda M (2006) Effect of pre-composting on vermicomposting of kitchen waste. Bioreso Technol 97:2091-2095. https://doi.org/10.1016/j.biortech.2005.09.020

Nazaryuk VM, Klenova MI, Kalimullina FR (2002) Eco-agrochemical approaches to the problem of nitrate pollution in agroecosystems. Russ J Ecol 33:392-397. https://doi.org/10.1023/A:1020995329 784

Obia A, Mulder J, Martinsen V, Cornelissen G, Børresen T (2016) Insitu effects of biochar on aggregation, water retention and porosity in light-textured tropical soils. Soil till Res 155:35-44. https://doi. org/10.1016/j.still.2015.08.002

Page AL, Miller RH, Keeney DR (1982) Methods of Soil Analysis: Part 2, Chemical and Microbiological Properties. Agronomy Series No 9, American Society of Agronomy, Madison, WI, p 13-776

Pavlou GC, Ehaliotis CD, Kavvadias VA (2007) Effect of organic and inorganic fertilizers applied during successive crop seasons on growth and nitrate accumulation in lettuce. Sci Hort 111:319-325. https://doi.org/10.1016/j.scienta.2006.11.003

Pinto E, Almeida A, Aguiar A, Ferreira I (2015) Comparison between the mineral profile and nitrate content of microgreens and mature lettuces. J Food Compos Anal 37:38-43. https://doi.org/10.1016/j. jfca.2014.06.018

Rutkowska B, Szulc W, Sosulski T, Stępień W (2014) Soil micronutrient availability to crops affected by long-term inorganic and organic fertilizer applications. Plant Soil Environ 60:198-203. https://doi.org/10.17221/914/2013-PSE 
Salehzadeh H, Maleki A, Rezaee R, Shahmoradi B, Ponnet K (2020) The nitrate content of fresh and cooked vegetables and their health-related risks. PLoS ONE 15:e0227551. https://doi.org/ 10.1371/journal.pone.0227551

Salem EMM, Kenawey MKM, Saudy HS, Mubarak M (2021) Soil mulching and deficit irrigation effect on sustainability of nutrients availability and uptake, and productivity of maize grown in calcareous soils. Comm Soil Sci Plant Anal 52:1745-1761. https:// doi.org/10.1080/00103624.2021.1892733

Santamaria P (2006) Nitrate in vegetables: toxicity, content, intake and EC regulation. J Sci Food Agric 86:10-17. https://doi.org/ $10.1002 /$ jsfa. 2351

Saudy HS, El-Metwally IM (2019) Nutrient utilization indices of NPK and drought management in groundnut under sandy soil conditions. Comm Soil Sci Plant Anal 50:1821-1828. https://doi.org/ 10.1080/00103624.2019.1635147

Saudy HS, El-Metwally IM, Abd El-Samad GA (2020) Physio-biochemical and nutrient constituents of peanut plants under bentazone herbicide for broad-leaved weed control and water regimes in dry land areas. J Arid Land 12:630-639. https://doi.org/10. 1007/s40333-020-0020-y

Saudy HS, El-Bially M, El-Metwally IM, Shahin MG (2021) Physiobiochemical and agronomic response of ascorbic acid treated sunflower (Helianthus Annuus) grown at different sowing dates and under various irrigation regimes. Gesunde Pflanzen 73:169-179. https://doi.org/10.1007/s10343-020-00535-1

Schiattone MI, Viggiani R, Di Venere D, Sergio L, Cantore V, Todorovic M, Perniola M, Candido V (2018) Impact of irrigation regime and nitrogen rate on yield, quality and water use efficiency of wild rocket under greenhouse conditions. Sci Hort 229:182-192. https://doi.org/10.1016/j.scienta.2017.10.036

Shi WM, Yao J, Yan F (2009) Vegetable cultivation under greenhouse conditions leads to rapid accumulation of nutrients, acidification and salinity of soils and groundwater contamination in SouthEastern China. Nutr Cycl Agroecosyst 83:73-84. https://doi.org/ 10.1007/s10705-008-9201-3

Sun RB, Zhang XX, Guo XS, Wang DZ, Chu HY (2015) Bacterial diversity in soils subjected to long-term chemical fertilization can be more stably maintained with the addition of livestock manure than wheat straw. Sci Found China 88:9-18. https://doi.org/10. 1016/j.soilbio.2015.05.007

Tabaglio V, Boselli R, Fiorini A, Ganimede C, Beccari P, Santelli S, Nervo G (2020) Reducing nitrate accumulation and fertilizer use in lettuce with modified intermittent nutrient film technique (NFT) system. Agron 10:1208. https://doi.org/10.3390/agron omy 10081208
Tafteh A, Sepaskhah AR (2012) Yield and nitrogen leaching in maize field under different nitrogen rates and partial root drying irrigation. Inter J Plant Prod 6:93-114

Thompson RB, Martínez-Gaitan C, Gallardo M, Giménez C, Fernández MD (2007) Identification of irrigation and N management practices that contribute to nitrate leaching loss from an intensive vegetable production system by use of a comprehensive survey. Agric Wat Manage 89:261-274. https://doi.org/10.1016/j.agwat. 2007.01.013

Tsiakaras G, Petropoulos SA, Khah EM (2014) Effect of GA 3 and nitrogen on yield and marketability of lettuce (Lactuca sativa L.). Aust J Crop Sci 8:127-132

Umar AS, Iqbal M (2007) Nitrate accumulation in plants, factors affecting the process, and human health implications: A review. Agron Sustain Dev 27:45-57. https://doi.org/10.1051/agro:2006021

Wassie H (2012) Appraisal of Erythrina bruci as a source for soil nutrition on nitisols of South Ethiopia. Int J Agric Biol 14:371-376

Yang L, Zhao F, Chang Q, Li T, Li F (2015) Effects of vermicomposts on tomato yield and quality and soil fertility in greenhouse under different soil water regimes. Agric Wat Mange 160:98-105. https://doi.org/10.1016/j.agwat.2015.07.002

Yeshiwas Y, Zewdie BYB, Chekol A, Walle A (2018) Effect of nitrogen fertilizer and farmyard manure on growth and yield of lettuce (Lactuca sativa L.). Int J Agric Res 13:74-79. https://doi.org/10. 3923/ijar.2018.74.79

Yu L, Tang J, Zhang R, Wu Q, Gong M (2013) Effects of biochar application on soil methane emission at different soil moisture levels. Biol Fertil Soil 49:119-128. https://doi.org/10.1007/ s00374-012-0703-4

Zandvakili OR, Barker AV, Hashemi M, Etemadi F, Autio WR, Weis S (2019) Growth and nutrient and nitrate accumulation of lettuce under different regimes of nitrogen fertilization. J Plant Nutr 42:1575-1593. https://doi.org/10.1080/01904167.2019.1617313

Zhou C, Gao W, QI F (2014) Effect of irrigation with slightly acidic electrolyzed water on lettuce photosynthesis under mild water stress. App Engine Agric 30:789-795

Watanabe FC, Olsen SR (1965) Test of an ascorbic acid method for determining phosphorus in water and $\mathrm{NaHCO}_{3}$ extracts from soils. Soil Sci Soc Amer J 29:677-678. https://doi.org/10.2136/sssaj $1965.03615995002900060025 x$

Publisher's Note Springer Nature remains neutral with regard to jurisdictional claims in published maps and institutional affiliations. 